Acta vet. scand. 1967, 8, 98-110.

From the Departments of Clinical Biochemistry and Obstetrics and Gynaecology, Royal Veterinary College, and the Research Institute of National Defense, Department 4, Stockholm, Sweden.

\title{
ON THE OCCURRENCE AND SIGNIFICANCE OF RADIOCESIUM IN BULL SEMEN
}

By

\author{
L. Ekman, U. Greitz, B. Gustafsson and C. B. Thorell
}

The metabolism of radiocesium in animals has been studied extensively during the last ten years (e.g. Hood \& Comar 1953; Ekman 1961; Wasserman et al. 1965). Radiocesium is distributed throughout the body with a somewhat higher concentration in some organs than in others, but the usual range of concentration from tissue to tissue does not exceed a factor of two. With regard to genetic risks the accumulation of radiocesium in the gonads has gained some attention. No special accumulation seems to occur neither in the ovary nor in the testes of any animal species investigated. Generally the concentration in the gonads is very similar to that in the liver (Ballou \& Thompson 1958; Ekman). In mice Nelson et al. (1961) noticed a somewhat higher concentration in the ovary of a pregnant animal than in a non-pregnant. Even if thus the concentration of radiocesium in the testes of small laboratory animals has been studied, there is, however, no investigation to our knowledge about the occurrence and distribution of cesium in the semen of bulls.

Cesium is, like potassium, known to be localized mainly intracellularly and there is in many tissues a considerable concentration factor between cells and blood plasma (e.g. Ekman). It is also apparent that, at tracer levels of $\mathrm{Cs}^{137}$, the relative partition of $\mathrm{Cs}^{137}$ and $\mathrm{K}^{+}$between plasma and most tissues is about 1 (Wasserman et al.). 
Exceptions from this general rule are the kidney with relatively more $\mathrm{Cs}^{137}$ (i.e. the ratio $\mathrm{Cs}_{\text {kidney }}^{137} / \mathrm{Cs}_{\text {plasma }}^{137}$ is greater than the ratio $\mathrm{K}_{\mathrm{kidney}}^{+} / \mathrm{K}_{\text {plasma }}^{+}$) and the brain with relatively less $\mathrm{Cs}^{137}$ (Ekman). Crabo (1964) has shown that the ratio $\mathrm{K}_{\text {spermatozoa }}^{+}$ $\mathrm{K}_{\text {seminal plasma }}^{+}$in bulls is about 1 . This is quite different from the usual intracellular to extracellular ratio of potassium which is known to be considerably greater than 1 . It was therefore thought to be of interest to determine the radiocesium ratio in spermatozoa/seminal plasma in bull semen and at the same time study the corresponding ratio in blood $\left(\mathrm{Cs}_{\text {blood cells }}^{\star} / \mathrm{Cs}_{\text {blood plasma }}^{\star}\right)$.

The modern deep-freezing technique has made it possible to store semen for many years. If there is radiocesium in the semen and especially if it is concentrated in the spermatozoa, this also means an increased risk for radiation damage to the spermatozoa. The dose to semen and spermatozoa has therefore been calculated for some practically feasible situations.

\section{MATERIAL AND METHODS}

Two bulls of the Swedish Red and White Breed, both with an age of four years were given $2.5 \mathrm{mCi} \mathrm{Cs}^{134}$ with a stomach tube. At varying time intervals (Fig. 2) semen was collected with an artificial vagina and the concentration of $\mathrm{Cs}^{134}$ measured in a well scintillation detector. After centrifugation the content of $\mathrm{Cs}^{134}$ in seminal plasma was determined in the same way. The concentration of $\mathrm{Cs}^{134}$ in the spermatozoa was measured after washing of the cells four times in MacLeod dilution liquid (cf. Bane 1952). All data were corrected for decay of $\mathrm{Cs}^{134}$ during the experiment. The sperm concentration in each ejaculate was determined by a hemacytometrical method. The occurrence of normal ejaculate volume, sperm concentration, motility and morphology was checked during one month before the start of the experiment. The same control was also performed on all ejaculates collected after the administration of $\mathrm{Cs}^{134}$. The methods used were those described by Lagerlöf (1934).

Blood samples were taken from the anterior jugular vein at gradually lengthening intervals and the radioactivity in whole blood and blood plasma measured. After determination of the hematocrit the concentration in the red cells could be calculated.

The weight of the two bulls, I and II, were 870 and $890 \mathrm{~kg}$ 
respectively, therefore, the experimental data obtained could be compared directly without any correction for differences in body weight.

\section{RESULTS AND DISCUSSION}

The concentration of $\mathrm{Cs}^{134}$ in blood plasma was decreasing rapidly during the first week after the administration (Fig. 1). The maximum level of $\mathrm{Cs}^{134}$ in blood cells was not reached until

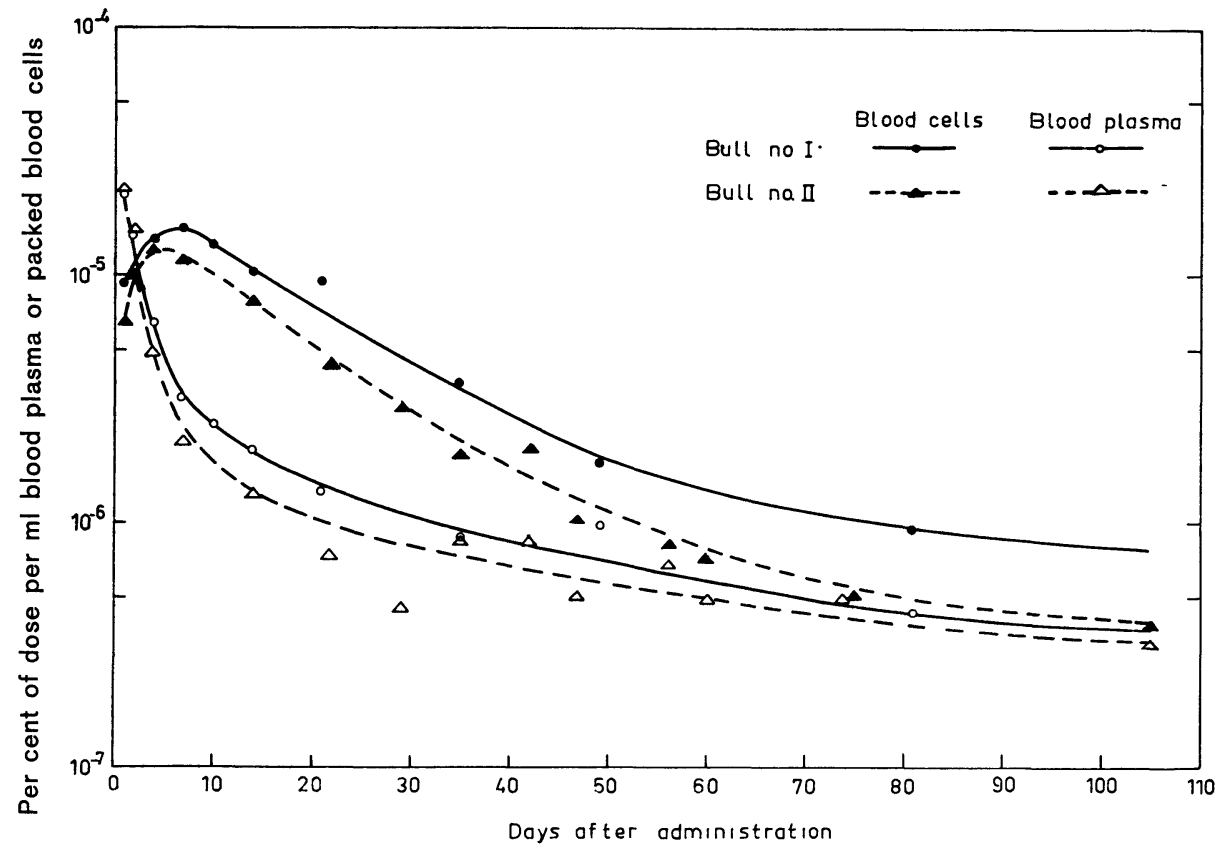

Figu re 1. The concentration of $\mathrm{Cs}^{134}$ in blood cells and plasma of bulls after a single oral administration.

four to seven days after the administration. The concentration of $\mathrm{Cs}^{134}$ was higher in blood cells than in blood plasma with the exception of the first two days after the administration. The difference in concentration between cells and plasma was considerably greater in bull I than in bull II. It can be concluded, however, that $\mathrm{Cs}^{134}$ in blood cells and blood plasma of bulls is following the same trend as has been shown in other animal species after oral administration (e.g. Ekman 1961).

The concentration of $\mathrm{Cs}^{134}$ in seminal plasma and spermatozoa of the two bulls at varying times after a single oral administration 


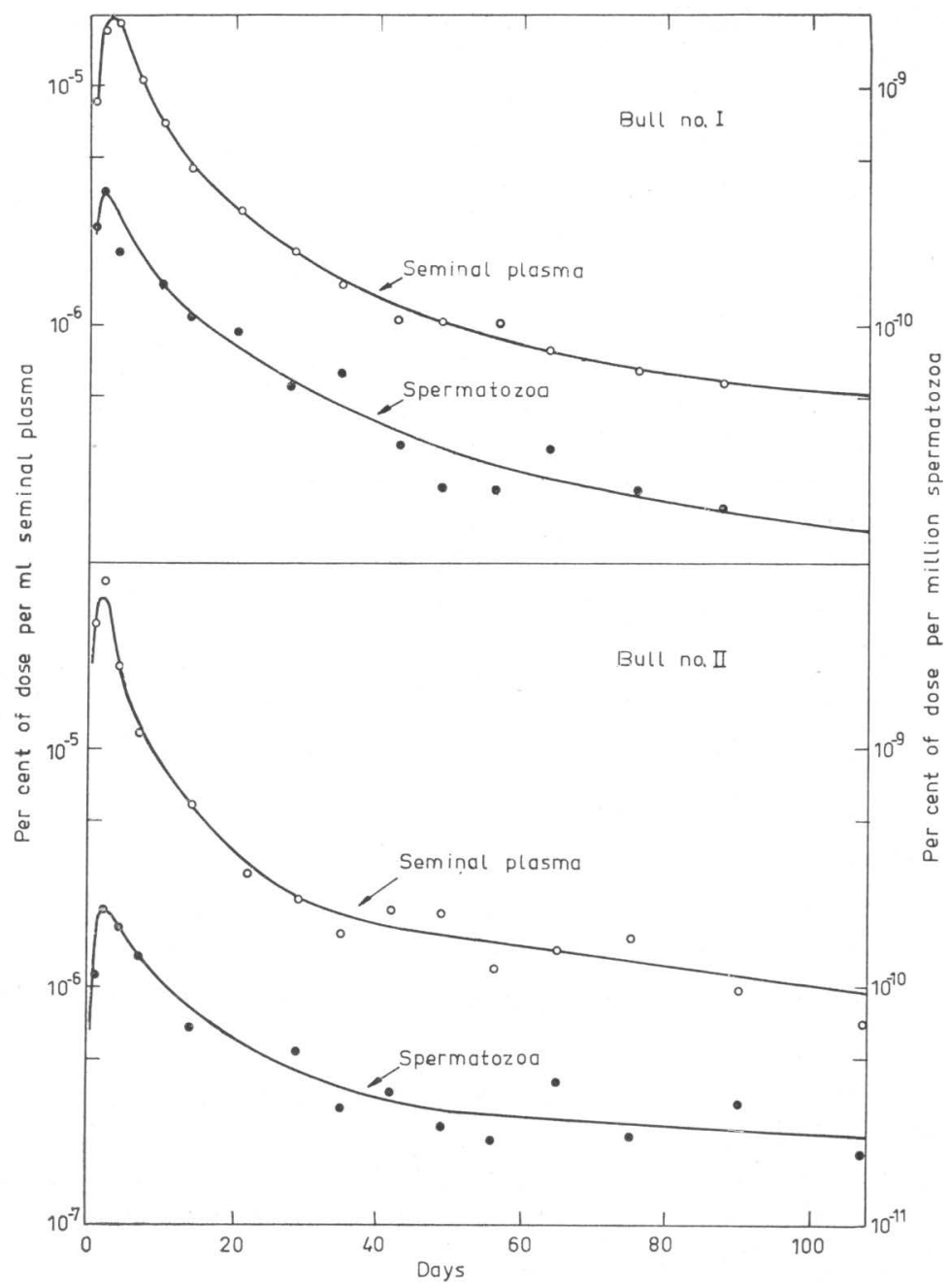

Fig u r e 2. The concentration of Cs ${ }^{134}$ in seminal plasma and spermatozoa of bulls after a single oral administration.

of $\mathrm{Cs}^{134}$ can be seen in Fig. 2. The highest concentration in both seminal plasma and sperm was reached on the second to fourth day after the administration. The shape of the curves a few days after giving $\mathrm{Cs}^{134}$ was similar in the two bulls, i.e. the ratio between the concentration of $\mathrm{Cs}^{134}$ in spermatozoa and seminal plasma was rather constant. This can be studied further in Table 1 where the mentioned ratio in each ejaculate from bull I is given. The $\mathrm{Cs}^{134}$-concentration in spermatozoa was only about 
T a b l e 1. Distribution of $\mathrm{Cs}^{137}$ in semen from bull no. I at different times after a single oral dose.

\begin{tabular}{|c|c|c|c|c|c|c|}
\hline $\begin{array}{l}\text { Days } \\
\text { after } \\
\text { admini- } \\
\text { stration }\end{array}$ & $\begin{array}{l}\begin{array}{c}\text { Per cent } \\
\text { of dose } \\
\text { per ml } \\
\text { semen }\end{array} \\
\times 10^{5} \\
\end{array}$ & $\begin{array}{c}\begin{array}{c}\text { Per cent } \\
\text { of dose } \\
\text { per ml } \\
\text { seminal } \\
\text { plasma }\end{array} \\
\times 10^{5} \\
\end{array}$ & $\begin{array}{c}\text { Per cent } \\
\text { of dose in } \\
\text { sperma } \\
\text { tozoa } \\
\text { per ml } \\
\text { semen } \\
\times 10^{5} \\
\end{array}$ & $\begin{array}{c}\begin{array}{c}\text { Number } \\
\text { of sper- } \\
\text { matozoa } \\
\text { per ml } \\
\text { semen }\end{array} \\
\times 10^{-9} \\
\end{array}$ & $\begin{array}{c}\text { Sperma- } \\
\text { tocrit } \\
\text { (per cent) }\end{array}$ & $\begin{array}{c}\text { Ratio of sper- } \\
\text { matozoa to } \\
\text { plasma con- } \\
\text { centration } \\
\text { of } \mathbf{C s}^{137}\end{array}$ \\
\hline 1 & 7.60 & 8.54 & 0.40 & 1.53 & 12.9 & 0.37 \\
\hline 2 & 16.5 & 17.7 & 0.36 & 1.01 & 8.5 & 0.24 \\
\hline 4 & 18.01 & 18.8 & 0.29 & 0.76 & 6.4 & 0.24 \\
\hline 7 & 10.1 & 10.7 & 0.12 & 1.13 & 9.5 & 0.12 \\
\hline 10 & 6.31 & 7.01 & 0.27 & 1.78 & 14.9 & 0.26 \\
\hline 14 & 4.13 & 4.50 & 0.17 & 1.61 & 13.5 & 0,28 \\
\hline 21 & 2.91 & 3.09 & 0.070 & 0.70 & 5.9 & 0.38 \\
\hline 28 & 1.87 & 2.05 & 0.091 & 1.20 & 10.1 & 0.44 \\
\hline 35 & 1.35 & 1.51 & 0.099 & 1.59 & 13.4 & 0.49 \\
\hline 43 & 0.99 & 1.08 & 0.054 & 1.74 & 14.6 & 0.34 \\
\hline 49 & 1.06 & 1.11 & 0.023 & 1.72 & 14.4 & 0.14 \\
\hline 57 & 0.94 & 0.99 & 0.027 & 1.38 & 11.6 & 0.24 \\
\hline 64 & 0.75 & 0.77 & 0.035 & 1.24 & 10.4 & 0.44 \\
\hline 81 & 0.59 & 0.63 & 0.035 & 1.68 & 14.1 & 0.39 \\
\hline \multirow[t]{2}{*}{88} & 0.49 & 0.57 & 0.033 & 1.98 & 16.6 & 0.35 \\
\hline & & & & & Mean va & 0.34 \\
\hline
\end{tabular}

$35 \%$ of that in seminal plasma. It should be pointed out that this figure is based on the results of measurements of $\mathrm{Cs}^{134}$ in whole semen and seminal plasma. After determination of the spermatocrit the concentration of $\mathrm{Cs}^{134}$ in packed sperm has been calculated. Therefore it can be concluded that the lower concentration in the spermatozoa has not been caused by any loss of $\mathrm{Cs}^{134}$ during washing procedures.

The reasons for the preferential accumulation of radiocesium in seminal plasma are unknown. One explanation could be that the secretion from e.g. the seminal vesicles has a comparatively high $\mathrm{Cs}^{134}$-content. The rapid appearance of $\mathrm{Cs}^{134}$ in semen and the observation that the ratio $\mathrm{Cs}_{\text {spermatozoa }}^{134} / \mathrm{Cs}_{\text {seminal plasma was }}^{134}$ relatively constant during the whole experimental period, seems to support the view that the distribution of radiocesium in semen will be accomplished after the sperm have left cauda epididymidis. An investigation of the distribution of radiocesium in the epididymal sperm and plasma will probably show if the suggested explanation is true. 
The concentration of $\mathrm{Cs}^{134}(\mathrm{~N}(\mathrm{t})=$ per cent of dose per $\mathrm{ml})$ in semen from bull $I$ after a single oral administration can be described by the expression:

$$
\begin{gathered}
\mathrm{N}(\mathrm{t})=\sum \mathrm{n}_{\mathrm{i}} \mathrm{e}^{-v_{\mathrm{i}}(\mathrm{t}-1)}=10^{-5}\left[2.2 \cdot \mathrm{e}^{-0.017(\mathrm{t}-1)}+13 \mathrm{e}^{-0.12(\mathrm{t}-1)}+\right. \\
\left.+37 \mathrm{e}^{-0,51(\mathrm{t}-1)}-45 \mathrm{e}^{-0.9(\mathrm{t}-1)}\right] \quad \mathrm{t} \geq 1
\end{gathered}
$$

The constants $n_{i}$ and $v_{i}$ are to be regarded as empirical with no biological or physical meaning. For $t<1$ day the expression is mostly negative and thus not applicable. The most long-lived term corresponds to a half life of 41 days.

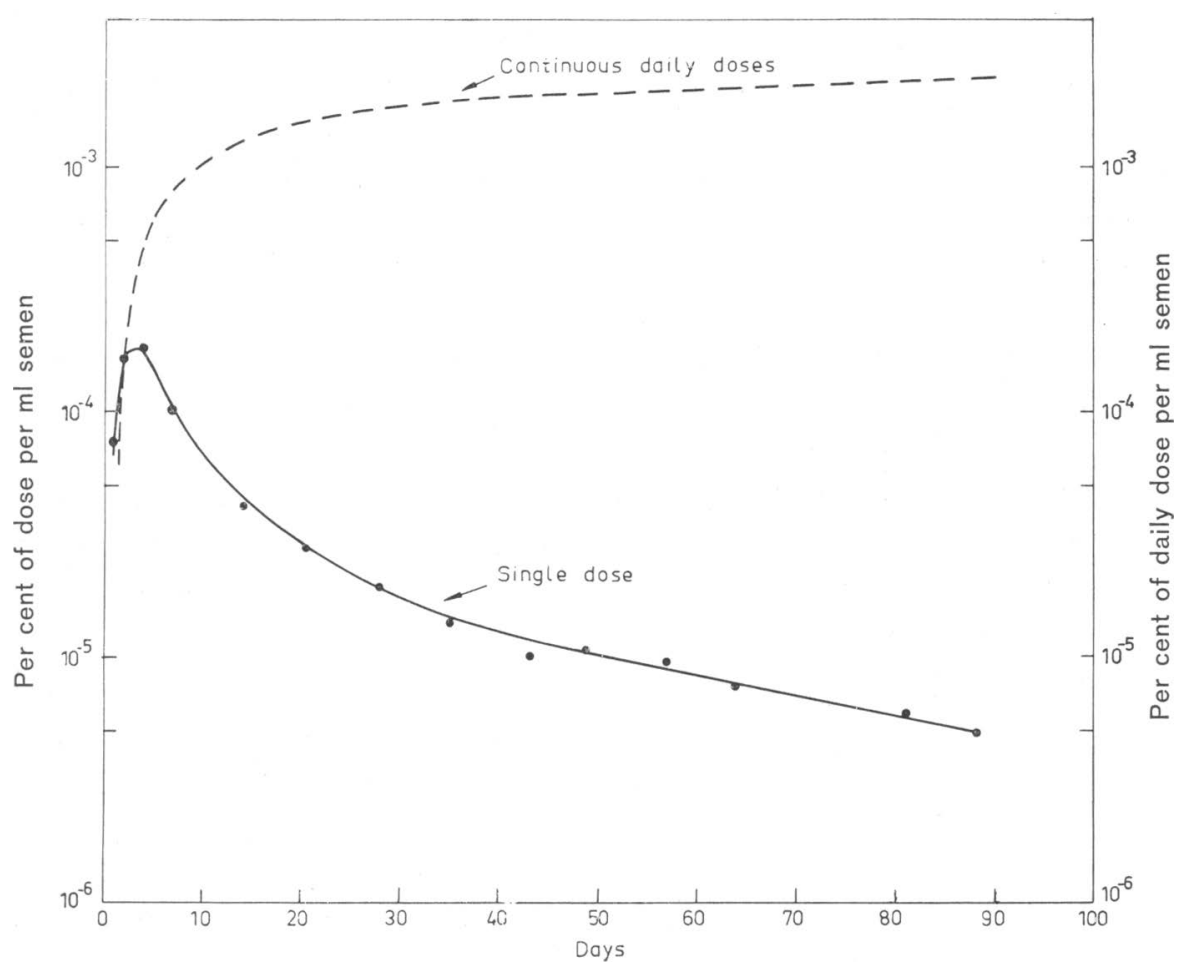

Fig u re 3. The theoretical curves describing the concentration of radiocesium in bull semen after single and daily doses of radiocesium. The obtained experimental data after a single oral dose to bull no. I are also given.

The curve describing the expression $\mathbf{N}(t)$ for radiocesium in bull semen can be seen in Fig. 3. It is obvious that the four-term expression describes the experimental data with good accuracy. 
For dose calculations it is of interest to know the concentration of radiocesium in semen after a continuous intake of radiocesium. A bull ingesting a unit amount at time $t^{\prime}$ will at later times show a concentration $N\left(t-t^{\prime}\right)$ in semen. The concentration $M(t)$ in semen after a continuous oral intake of a unit amount per day will thus be:

$$
\begin{array}{r}
\mathrm{M}(\mathrm{t})=\int_{0}^{\mathrm{t}-1} \mathrm{~N}\left(\mathrm{t}-\mathrm{t}^{\prime}\right) \mathrm{dt} \mathrm{t}^{\prime}=\sum \frac{\mathrm{n}_{\mathrm{i}}}{\nu_{\mathrm{i}}}\left[1-\mathrm{e}^{-v_{\mathrm{i}}(\mathrm{t}-1)}\right]= \\
10^{-5}\left[129\left(1-\mathrm{e}^{-0.017(\mathrm{t}-1)}\right)+108\left(1-\mathrm{e}^{-0.12(t-1)}\right)+\right. \\
\left.+73\left(1-\mathrm{e}^{-051(\mathrm{t}-1)}\right)-50\left(1-\mathrm{e}^{0.9(\mathrm{t}-1)}\right)\right] \text { where } \mathrm{t} \geq 1
\end{array}
$$

The curve describing the expression $M(t)$ for radiocesium in bull semen can also be seen in Fig. 3. After an infinite daily intake the concentration will be $2.6 \times 10^{-3} \%$ of the daily dose per $\mathrm{ml}$ semen. This value can be used for dose calculations at equilibrium concentration.

Doses to spermatozoa in testis and epididymis

$\mathrm{Cs}^{137}$ is the dominating cesium isotope produced in fission. All dose calculations have therefore been made on this isotope.

The beta-dose to the spermatozoa in testis and epididymis can be calculated if we assume that the $\mathrm{Cs}^{137}$ concentration in the testis and epididymis is about the same as that of semen. The beta-dose from $\mathrm{Cs}^{137}$ is :

$$
\frac{0.24 \times 1.6 \times 10^{-6}}{100}=3.8 \times 10^{-9} \mathrm{rads} \times \mathrm{cm}^{3} \times(\mathrm{dis})^{-1}
$$

0.24 is the effective beta energy of $\mathrm{Cs}^{137}$ in $\mathrm{MeV} .1 \mathrm{MeV}=1.6 \times$ $10^{-6}$ erg.

Overall mean body density assumed equal to $1.0 \mathrm{~g} \times \mathrm{cm}^{-3}$.

The gamma-dose to the spermatozoa in testis and epididymis is mainly due to $\mathrm{Cs}^{137}$ in the total body of the bull. The $\mathrm{Cs}^{137}$ concentration in the body can be assumed to be twice as high as that in testis and epididymis (probably less in reality).

For an approximate calculation of the gamma-dose to testis and epididymis (and to the spermatozoa) the bull body can be regarded as a sphere and the testis and epididymis as situated at the surface of this sphere. 
The following nomenclature is used:

$\Phi_{\mathrm{s}}$ Scalar flux at surface of sphere $\left(\gamma \times \mathrm{cm}^{-2} \times \mathrm{sec}^{-1}\right)$

B Symbolic build up factor (approximated to 1.0 in the calculations)

$S_{v} \quad$ Source strength of volume source $\left(\gamma \times \mathrm{cm}^{-3} \times \mathrm{sec}^{-1}\right)$

$\mu_{s}$ Macroscopic cross-section of cource material $\left(\mathrm{cm}^{-1}\right)$ (0.082 for $\left.\mathrm{Cs}^{137}\right)$

$R_{o}$ Radius of sphere (cm). (The bull body weight of $870 \mathrm{~kg}$ corresponds to a radius of about $60 \mathrm{~cm}$ )

E Energy of $\gamma$-source $(\mathrm{MeV} / \gamma)\left(0.662\right.$ for $\left.\mathrm{Cs}^{137}\right)$

$\mu \quad$ Energy absorption coefficient $\left(\mathrm{cm}^{-1}\right)\left(0.032\right.$ for $\left.\mathrm{Cs}^{137}\right)$.

According to Rockwell (1956) the scalar flux is:

$$
\Phi_{\mathrm{s}}=\frac{\mathrm{B} \times \mathrm{S}_{\mathrm{v}}}{2 \mu_{\mathrm{s}}} \quad\left(1-\frac{1}{2 \mu_{\mathrm{s}} \mathrm{R}_{\mathrm{o}}}+\frac{\mathrm{e}^{-2 \mu_{\mathrm{s}} \mathrm{R}_{\mathrm{o}}}}{2 \mu_{\mathrm{s}} \mathrm{R}_{\mathrm{o}}}\right)
$$

By inserting of pertinent values we get

$$
\Phi_{\mathrm{s}}=5.5 \mathrm{~S}_{\mathrm{v}} \gamma \times \mathrm{cm}^{-2} \times \mathrm{sec}^{-1}
$$

The gamma-dose to spermatozoa in testis and epididymis is then:

$\Phi_{\mathrm{s}} \times \mu \times \mathrm{E} \times 1.6 \times 10^{-8}=5.5 \times 0.032 \times 0.662 \times 1.6 \times 10^{-8}=$

$$
=1.86 \times 10^{-9} \mathrm{rads} \times \mathrm{cm}^{3} \times(\gamma)^{-1}
$$

and the total dose from $\mathrm{Cs}^{137}$ is:

$$
\begin{aligned}
3.8 \times 10^{-9}+0.82 \times 2 \times 1.86 \times 10^{-9}= \\
6.9 \times 10^{-9} \mathrm{rads} \times \mathrm{cm}^{3} \times(\mathrm{dis})^{-1}
\end{aligned}
$$

The factor 0.82 is the number of $0.662 \mathrm{MeV}$ photons per $\mathrm{Cs}^{137}$ disintegration and the factor 2 is the ratio of the $\mathrm{Cs}^{137}$-concentration in total body to that in testis and epididymis.

Doses to spermatozoa stored in semen banks

To examine if there is any genetic risk to store semen for long time periods the radiation doses to spermatozoa must be calculated. In Sweden it is common to store the semen in glass ampoules which are placed in the banks close together in a 
square arrangement consisting in all of 81 tubes. Each ampoule contains $1.2 \mathrm{ml}$ semen. It has an outer radius of $0.5 \mathrm{~cm}$ and an inner of $0.45 \mathrm{~cm}$.

Owing to the short beta range the beta-dose from $\mathrm{Cs}^{137}$ in the main semen mass will be $3.8 \times 10^{-9} \mathrm{rads} \times \mathrm{cm}^{3} \times(\mathrm{dis})^{-1}$ (cf. p. 104).

For an approximate calculation of the gamma-dose we replace the square arrangement with a right cylinder homogeneously filled with activity. This cylinder has a base area of $81 \mathrm{~cm}^{2}$ corresponding to the area of the tube arrangement and it has a height of $1.9 \mathrm{~cm}$ corresponding to the height of the semen in the ampoules. Its specific activity is $0.45^{2} \times \pi$ times the specific activity of the semen. The formula for the central flux in a cylinder is:

$$
\Phi_{c}=\frac{B \times S_{v}}{\mu_{s}} \times G\left(\mu_{s} h_{1}, b\right) \gamma \times \mathrm{cm}^{-2} \times \text { sec. }^{-1} \text { (Rockwell). }
$$

The function $G\left(\mu_{s} h_{1}, b\right)$ is given by Rockwell in graphical form and was calculated to be equal to 0.18 . Now one gets:

$$
\Phi_{\mathrm{c}}=\frac{\mathrm{S}_{\mathrm{v}}}{0.082} \times 0.18=2.2 \mathrm{~S}_{\mathrm{v}} \gamma \times \mathrm{cm}^{-2} \times \mathrm{sec}^{-1}
$$

The gamma-dose to the spermatozoa is then:

$$
\begin{aligned}
\pi \times 0.45^{2} \times \Phi_{\mathrm{c}} \times \mu \times \mathrm{E} \times 1.6 \times 10^{-8} & = \\
0.48 & \times 10^{-9} \mathrm{rads} \times \mathrm{cm}^{3}(\gamma)^{-1}
\end{aligned}
$$

To correspond to the actual $\mathrm{Cs}^{137}$ distribution in the square arrangement the factor $\pi \times 0.45^{2}$ must evidently be used.

The total dose from $\mathrm{Cs}^{137}$ to the spermatozoa in the semen bank is then:

$3.8 \times 10^{-9}+0.82 \times 0.48 \times 10^{-9}=4.2 \times 10^{-9} \mathrm{rads} \times \mathrm{cm}^{3} \times(\mathrm{dis})^{-1}$ (the factor 0.82 is explained on p. 105).

Doses to spermatozoa in a bull grazing in a fallout area

It is of interest to relate a given deposition of fallout on pasture and the dose to spermatozoa in bulls grazing on the pasture.

We assume a deposition of $3.4 \times 10^{15}$ fissions $/ \mathrm{m}^{2}$ which corresponds to a dose rate of about $100 \mathrm{r} / \mathrm{hr}$. at $1 \mathrm{hr}$. after fission. 
The consumption of the bulls can be assumed to be $170 \mathrm{~m}^{2} /$ day (Garner 1960). Further on assuming $0.2 \%$ of deposited $\mathrm{Cs}^{137}$ being taken up by the grass and consumed by the bull one can calculate that about $1.5 \mu \mathrm{Ci} \mathrm{Cs}{ }^{137}$ is consumed by the bull per day.

It has previously been shown that a bull ingesting $1 \mu \mathrm{Ci}$ per day will show an equilibrium concentration of $2.6 \times 10^{-5} \mu \mathrm{Ci}$ per ml semen.

As the dose to spermatozoa in testis and epididymis from $\mathrm{Cs}^{137}$ is $6.9 \times 10^{-9}$ rads $\times \mathrm{cm}^{3} \times(\mathrm{dis})^{-1}$ one finds that during an assumed maximum residence time of 70 days in testis and epididymis, the dose will be about $60 \mathrm{mrad}$. The dose to spermatozoa which have been diluted ten times ( 10 to 20 is a common dilution rate) and then stored in a semen bank for one year, will be about 20 mrad. In all the total dose will thus not exceed 0.1 rad. It seems unlikely that the radiation dose to sperm from $\mathrm{Cs}^{137}$ deposited in the body and in the semen will be of any significance in comparison with e.g. the external dose received from fallout.

\section{REFERENCES}

Ballou, J. E. \& R. C. Thompson: Metabolism of cesium-137 in the rat: Comparison of acute and chronic administration experiments. Health Phys. 1958, 1, 85-89.

Bane, A.: A study on the technique of hemocytometric determination of sperm motility and sperm concentration in bull semen. Cornell Vet. 1952, 42, 518-531.

Crabo, B.: Concentration of sodium, potassium and chloride in epididymal plasma and sperm of bulls. Proc. Vth Int. Congr. Animal Reprod., Trento 1964, 4, 566-571.

Ekman, L.: Distribution and excretion of radio-cesium in goats, pigs and hens. Acta vet. scand. 1961, 2, Suppl. 4, 83 pp.

Garner, $R$. J.: An assessment of the quantities of fission products likely to be found in milk in the event of aerial contamination of agricultural land. Nature (Lond.) 1960, 186, 1063-1064.

Hood, S. L. \& L. C. Comar: Metabolism of cesium-137 in rats and farm animals. Arch. Biochem. 1953, 45, 423-433.

Lagerlöf, N.: Morphologische Untersuchungen über Veränderungen im Spermabild und in den Hoden bei Bullen mit verminderten oder aufgehobener Fertilität. Thesis, Stockholm 1934.

Nelson, A., S. Ullberg, H. Kristoffersen \& C. Rönnbäck: Distribution of radiocesium in mice. Acta radiol. (Stockh.) 1961, 55, 374-384.

Rockwell, T.: III. Reactor Shielding Design Manual. van Nostrand, New York 1956. 
Wasserman, R. H., F. W. Lengemann, J. C. Thompson Jr. \& C. L. Co mar: The transfer of fall-out radionuclides from diet to man. In, Radioactive Fallout, Soils, Plants, Foods, Man, ed. E. B. Fowler, Elsvier 1965, 204-244.

\section{SUMMARY}

A study has been carried out to investigate the distribution and concentration of radiocesium in bull semen after oral administration. Two bulls were given $2.5 \mathrm{mCi} \mathrm{Cs}^{134}$ in water solution with a stomach tube. Semen was collected with an artificial vagina and the concentration of $\mathrm{Cs}^{134}$ in seminal plasma and spermatozoa measured. The concentration of $\mathrm{Cs}^{134}$ in blood plasma and blood cells was also determined at various time intervals after the administration.

From one week up to the end of the experimental period (88 and 107 days respectively) the ratio between the concentration of $\mathrm{Cs}^{134}$ in spermatozoa and seminal plasma was fairly constant. The concentration in the spermatozoa was only about $35 \%$ of that in seminal plasma. This is remarkable since the intracellular concentration of cesium usually is higher than the extracellular. The concentration of Cs $^{134}$ in the blood cells of the two bulls was also considerably higher than that in the blood plasma.

The concentration of $\mathrm{Cs}^{134}$ in semen from a bull could be described by a four-term exponential expression. In consequence it could be calculated that the concentration after an infinite daily intake will be $2.6 \times 10^{-3} \%$ of the daily dose per ml semen.

If the deposition of fallout on the pasture where a bull is grazing is $3.4 \times 1015$ fissions $/ \mathrm{m}^{2}$ (corresponding to a dose rate of about $100 \mathrm{r} / \mathrm{hr}$. at $1 \mathrm{hr}$. after fission), the dose to spermatozoa in testis and epididymis from $\mathrm{Cs}^{137}$ will be about $60 \mathrm{mrad}$ assuming a maximum residence time of 70 days of the spermatozoa in testis and epididymis. The dose to the spermatozoa which have been diluted ten times (10 to 20 is a common dilution rate) and then stored in a semen bank for one year, will be about 20 mrad. In all the total dose will thus not exceed 0.1 rad. It seems unlikely that the radiation dose to sperm from $\mathrm{Cs}^{137}$ deposited in the body and in the semen will be of any significance in comparison with. e.g. the external dose received from fallout.

\section{ZUSAMMENFASSUNG}

Uber das Vorkommen und die Bedeutung von Radiocesium im Bullensperma.

Eine Untersuchung ist vorgenommen worden, um die Verteilung und Konzentration von Radiocesium im Bullensperma nach oraler Eingabe zu studieren. Zwei Bullen erhielten 2,5 $\mathrm{mCi} \mathrm{Cs}^{134}$ in Wasserlösung mit der Magensonde. Die Spermien wurden mit einer artifiziellen Vagina aufgesammelt und danach wurde die Konzentration von $\mathbf{C s}^{\mathbf{1 3 4}}$ im Spermaplasma und in den Spermien bestimmt. Als Vergleich wurde 
auch die Cs ${ }^{134}$ Konzentration im Blutplasma und in den Blutkörperschen untersucht.

Nach zirka einer Woche bis zum Schluss der Versuchsperiode nach 88 bzw. 107 Tagen, war das Verhältnis der Cs ${ }^{134}$ Konzentration zwischen den Spermien und dem Spermaplasma ziemlich konstant. Die Konzentration in den Spermien betrug nur zirka $35 \%$ der im Spermaplasma, welches als anmerkungswert zu bezeichnen ist, da gewöhnlich die intracelluläre Cesiumkonzentration höher ist als die extracelluläre. Im Blut der untersuchten Stiere war also die $\mathrm{Cs}^{134}$ Konzentration in den Blutkörperchen bedeutend höher als im Blutplasma.

Die Konzentrationskurve für Cs ${ }^{134}$ im Sperma vom Bullen konnte mathematisch als eine Summe von vier Exponentialthermen beschrieben werden. An Hand dessen konnte berechnet werden, dass die Konzentration im Sperma bei kontinuierlicher Eingabe von Radiocesium $2.6 \times 10^{-3} \%$ der täglichen Dosis per ml Sperma sein wird.

Wenn die Deposition auf der Weide eines Stieres $3.4 \times 1015$ Fissionen $/ \mathrm{m}^{2}$, entsprechend einer Dosengeschwindigkeit von $100 \mathrm{r} / \mathrm{hr}$. eine Stunde nach der Fission ist, wird die Strahlendosis von $\mathrm{Cs}^{137}$ auf die Spermien unter der Passage von den Testikeln und durch die Bitestikel ungefähr 60 mrd sein, unter der Voraussetzung, dass die maximale Aufenthaltszeit in den Testikeln und Bitestikeln 70 Tage ist. Nach einjähriger Aufbewarung in der Spermabank, wird die Strahlendosis zirka $20 \mathrm{mrd}$ und damit die totale Dosis auf die Spermien $0.1 \mathrm{rad}$ sein. Es ist deshalb unwahrscheinlich, dass die Strahlendosis vom Cs $^{137}$ auf die Spermien, im Vergleich mit z. B. den externen Dosen vom Radiakbelag, von Bedeutung sein wird.

\section{SAMMANFATTNING}

Om förekomst och betydelse av radiocesium i tjursperma.

En undersökning har utförts för att studera fördelningen och koncentrationen av radiocesium i tjursperma efter oral ingivning. Två tjurar erhöll $2.5 \mathrm{mCi} \mathrm{Cs}^{134}$ i vattenlösning med magsond. Sperman uppsamlades med artificiell vagina varefter koncentrationen av $\mathrm{Cs}^{134}$ i spermaplasma och spermatozoer bestämdes. Som jämförelse undersöktes även Cs ${ }^{134}$-koncentrationen i blodplasma och blodkroppar.

Efter ca. en vecka fram till försöksperiodens slut efter 88 resp. 107 dagar, var förhållandet mellan koncentrationen av $\mathbf{C s}^{134}$ i spermatozoer och spermaplasma ganska konstant. Koncentrationen i spermatozoerna var endast ca. $35 \%$ av den i spermaplasma, vilket är anmärkningsvärt eftersom den intracellulära cesiumkoncentrationen vanligtvis är högre än den extracellulära. I blodet från de undersökta tjurarna var således blodkropparnas Cs ${ }^{134}$-koncentration betydligt högre än blodplasma.

Koncentrationskurvan för $\mathrm{Cs}^{134}$ i sperma från tjur kunde matematiskt beskrivas som en summa av fyra exponentialtermer. Med ledning härav kunde beräknas att koncentrationen i sperma vid ett kontinuerligt intag av radiocesium kommer att bli $2.6 \times 10^{-3}$ procent av dagliga dosen per ml sperma. 
Om depositionen på en tjurs betesmark är $3.4 \times 1015$ fissioner $/ \mathrm{m}^{2}$ motsvarande en doshastighet av $100 \mathrm{r} / \mathrm{hr}$. en timme efter fission kommer stråldosen till spermatozoerna från Cs ${ }^{137}$ under passagen från testikel och genom bitestikel att bli omkring 60 mrad förutsatt att maximala uppehållstiden för spermierna $i$ testikel och bitestikel är 70 dagar. Efter förvaring i spermabank under ett år blir stråldosen omkring $20 \mathrm{mrad}$ och således totala dosen till spermatozoerna omkring 0.1 rad. Det är därför osannolikt att stråldosen till spermierna från $\mathrm{Cs}^{137}$ kommer att vara av någon betydelse i jämförelse med $t$. ex. den externa dosen från radiakbeläggning.

(Received October 8, 1966). 